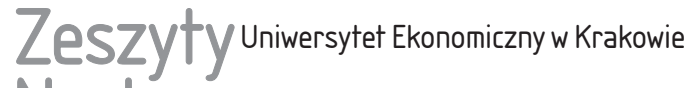 Naukowe
}

\section{Analiza porównawcza zastosowania modeli Roychowdhury'ego i Gunny w estymacji realnego zarządzania zyskiem}

\section{Streszczenie}

Cel: Celem artykułu jest przedstawienie wyników badań empirycznych dotyczących kształtowania uznaniowych kosztów produkcji oraz dyskrecjonalnych kosztów sprzedaży i kosztów ogólnego zarządu w spółkach publicznych zaszeregowanych do indeksu WIG-budownictwo. Ponadto celem artykułu jest analiza relacji między zakresem implementowanych praktyk rzeczowego zarządzania zyskiem (REM) a dokonaniami przedsiębiorstw giełdowych ocenianych na podstawie wskaźnika $R O A$.

Metodyka badań: Do określenia skali realnego zarządzania zyskiem wykorzystano formuły analityczne autorstwa S. Roychowdhury'ego i K.A. Gunny.

Wyniki badań: Wykazano, że w badanej populacji istnieją statystycznie istotne związki między osiąganą rentownością netto aktywów a skalą wdrażanych praktyk REM. Udowodniono, że związki między współczynnikami $R E M$, wyodrębnianymi za pomocą odmiennych modeli regresyjnych, to zależności o bardzo dużej sile.

Wnioski: W odniesieniu do dyskrecjonalnych kosztów sprzedaży i kosztów ogólnego zarządu przyjęty sposób szacowania ich poziomu w większym stopniu wpływa na ogólną

Michał Comporek, Uniwersytet Łódzki, Katedra Analizy i Strategii Przedsiębiorstwa, ul. Rewolucji 1905 r.nr 37, 90-214 Łódź, e-mail: michal.comporek@uni.lodz.pl, ORCID: https://orcid. org/0000-0002-1402-2505.

Artykuł udostępniany na licencji Creative Commons Uznanie autorstwa-Użycie niekomercyjne-Bez utworów zależnych 4.0 (CC BY-NC-ND 4.0); https://creativecommons.org/licenses/ by-nc-nd/4.0/ 
ocenę skali praktyk REM w jednostce gospodarczej aniżeli w przypadku analizy uznaniowych kosztów produkcji.

Wkład w rozwój dyscypliny: Zrealizowane badania wydają się istotne z perspektywy poszukiwania skutecznych instrumentów pomiaru działań z zakresu realnego kształtowania wyniku finansowego jednostki.

Słowa kluczowe: realne zarządzanie zyskiem, model Roychowdhury'ego, model Gunny, przedsiębiorstwa budowlane.

Klasyfikacja JEL: G32, M40.

\section{Wprowadzenie}

W szerokim wymiarze znaczeniowym zjawisko zarządzania zyskiem (earnings management) może być rozumiane jako ogół celowych działań zmierzających do wykazywania w sprawozdaniu finansowym wielkości księgowych, które normalnie nie miałyby swojego odzwierciedlenia w osiąganych efektach działania jednostki gospodarczej. W literaturze przedmiotu wyodrębnia się dwie główne drogi rozmyślnego kształtowania wyniku finansowego przedsiębiorstwa. Pierwsza, utożsamiana $\mathrm{z}$ rachunkowym stymulowaniem zysku (straty) w podmiocie gospodarczym (accrual-based earnings management - AEM), wiąże się z wykorzystaniem elastyczności i uznaniowości w sprawozdawczości finansowej w celu uwidocznienia zamierzonych rezultatów jednostki. Druga zaś, określana mianem realnego (rzeczowego) zarządzania zyskiem (real earnings management - REM), ogranicza się do intencjonalnego podejmowania decyzji gospodarczych o charakterze operacyjnym, inwestycyjnym bądź finansowym (Gandhi 2019, s. 257), które mogą oddziaływać na poziom raportowanego wyniku zgodnie ze wskazaniami kadry zarządzającej.

Do najczęściej przytaczanych w literaturze przedmiotu modeli służących do szacowania skali $R E M$ na różnych szczeblach działalności przedsiębiorstwa należą formuły analityczne autorstwa S. Roychowdhury'ego (2006) oraz K.A. Gunny (2010). O ile jednak metodologia S. Roychowdhury'ego opiera się przede wszystkim na wykorzystaniu wartości generowanych przychodów ze sprzedaży jako podstawowej zmiennej objaśniającej skalę praktyk z zakresu REM w jednostce gospodarczej, o tyle K.A. Gunny w swoich rozważaniach wzięła pod uwagę zróżnicowane zmienne egzogeniczne, odnoszące się zarówno do poziomu generowanych przychodów ze sprzedaży, jak i miar ilustrujących: poziom kapitału intelektualnego w jednostce, wartość rynkową jednostki, zakres finansowania wewnętrznego, przychody ze sprzedaży rzeczowych aktywów trwałych czy też zyski ze zbycia inwestycji długoterminowych. 
Zasadniczym celem artykułu jest przedstawienie wyników badań empirycznych dotyczących kształtowania uznaniowych kosztów produkcji $\left(P R O D_{d i s c}\right)$ oraz dyskrecjonalnych kosztów sprzedaży i kosztów ogólnego zarządu $\left(S G \& A_{\text {disc }}\right)$ w spółkach publicznych zaszeregowanych do indeksu WIG-budownictwo. Wspomniane dwie przestrzenie kognitywne (tj. analiza pozytywnego, ponadprzeciętnego poziomu kosztów produkcji $P R O D_{\text {disc }}$ oraz negatywnego, ponadprzeciętnego poziomu kosztów sprzedaży i ogólnego zarządu $S G \& A_{\text {disc }}$ ) zostały odrębnie wyeksponowane w instrumentach prognoz i diagnostyki kształtowania REM opracowanych zarówno przez S. Roychowdhury'ego, jak i K.A. Gunny. Skonfrontowanie tych alternatywnych podejść do oceny praktyk $R E M$ pozwoliło na ukazanie wzajemnych zależności między obliczonymi wartościami współczynników $P R O D_{\text {disc }}$ i $S G \& A_{\text {disc }}$ oraz uzyskanie odpowiedzi na pytanie, czy wartości tych wskaźników różniły się w sposób istotny statystycznie w przedsiębiorstwach charakteryzujących się zróżnicowanym poziomem generowanej rentowności netto aktywów.

Zrealizowane badania empiryczne mają charakter egzemplifikacyjny. Ograniczają się do analizy 27 publicznych spółek akcyjnych (łącznie 290 obserwacji) prowadzących działalność gospodarczą w sektorze „budownictwo”, których akcje były przedmiotem obrotu na Giełdzie Papierów Wartościowych w Warszawie przez okres minimum dziewięciu lat (w przyjętym horyzoncie odniesienia 2006-2018). Dodatkowym kryterium kwalifikującym przedsiębiorstwa do badań była dostępność rocznych jednostkowych sprawozdań finansowych. Za podstawową metodę oceny kształtowania praktyk z zakresu REM przyjęto analizę regresji, na podstawie której - z otrzymanych wyników badań wskazanego zbioru predykatorów - wyjaśniona została koincydencja z wybraną zmienną zależną. W artykule wykorzystane zostały również inne metody statystyczne, pomocne m.in. w ocenie stopnia dopasowania poszczególnych modeli do danych empirycznych. Należy także wskazać, że analizy empiryczne zostały zrealizowane na podstawie danych finansowych zaczerpniętych z bazy danych Notoria Serwis SA oraz Roczników Giełdowych GPW w Warszawie.

\section{Istota i wymiary realnego zarządzania zyskiem - zarys problematyki}

Terminologiczne ujęcie praktyk wchodzących w skład REM przedstawiane jest w literaturze przedmiotu w sposób wysoce zdywersyfikowany. W zaprezentowanych w tabeli 1 przykładach heterogenicznych treści znaczeniowych zjawiska $R E M$ znajdują odzwierciedlenie opcje kształtowania wyniku finansowego za pośrednictwem operacji gospodarczych odznaczających się wyraźnie negatywnym wpływem na kształtowanie przyszłej wartości przedsiębiorstwa, 
jego konkurencyjność rynkową oraz długookresowe perspektywy. Jednocześnie działania wpisujące się w nurt omawianej koncepcji stymulowania wyniku wyraźnie różnią się od praktyk zarządzania zyskiem opartych na rozwiązaniach rachunkowych $(A E M)$. Ich cechami charakterystycznymi są bowiem: bardziej kosztochłonna implementacja, mniejsze ryzyko wykrycia „intencjonalności” niskich motywów podejmowanych działań, praktycznie brak możliwości wykrycia tego typu praktyk przez osoby z zewnętrz organizacji (operacje te w praktyce nie podlegają jurysdykcji żadnego istniejącego systemu kontroli i rzadziej są przedmiotem zewnętrznego monitorowania przez audytorów, społeczeństwo, media itd.), czy też możliwość wdrażania w całym okresie trwania roku obrachunkowego (Vladu 2015, s. 414; Comporek 2019, s. 144). Pomimo swojego wysoce szkodliwego charakteru praktyki z obszaru REM często znajdują odbicie w rzeczywistości gospodarczej. W licznych opracowaniach z zakresu earnings management udowodniono, że menedżerowie - stojąc przed dylematem wyboru między AEM i $R E M$ - często preferować będą implementację drugiej z wymienionych koncepcji wpływania na wynik finansowy przedsiębiorstwa - zob. np. (Gunny 2005, Braam i in. 2015, Vladu 2015). Ma to swoje wytłumaczenie m.in. w koncepcji stakeholders value, hipotezie planu premiowego czy założeniach teorii agencji.

Należy podkreślić, że w przyjętych i stosowanych narzędziach REM zauważalne są szerokie i złożone metodycznie rozwiązania pozwalające na wielokierunkowe wdrażanie działań zorientowanych na „sztuczne” kształtowanie wyniku finansowego poprzez podejmowane transakcje gospodarcze. Praktyki te zwyczajowo koncentrują się wokół:

- odraczania wydatków na badania i rozwój, a także innych kosztów uznaniowych (np. kosztów marketingowych, kosztów administracyjnych, kosztów ogólnego zarząadu) w celu zwiększenia raportowanych zysków w okresie bieżącym (Bushee 1998, s. 305-333; Graham, Harvey i Rajgopal 2005, s. 3-73),

- strukturalizacji i zarządzaniu czasem (timing) podejmowanych operacji gospodarczych,

- sprzedaży aktywów przynoszących dodatkowy zysk dla przedsiębiorstwa lub intencjonalnego operowania terminem ujęcia przychodów ze zbycia tych aktywów (Bartov 1993, s. 840-855; Gunny 2010, s. 855-888),

- wdrażania odmiennych strategii gospodarowania zapasami (np. zmian harmonogramów wysyłek produktów gotowych i towarów, nadprodukcji, ponadprzeciętnej redukcja kosztów sprzedaży) (Thomas i Zhang 2002, s. 163-187),

- ponadnormatywnego obniżenia cen produktów w celu zwiększenia sprzedaży w bieżącym okresie oraz stosowania innych środków służących do przyspieszenia sprzedaży (np. liberalne strategie gospodarowania należnościami krótkoterminowymi) (Jackson i Wilcox 2000, s. 3-20; Roychowdhury 2006, s. 335-370),

- wykupu i umarzania akcji własnych (Hribar, Jenkins i Johnson 2006, s. 3-27), 
- wykorzystania instrumentów pochodnych i instrumentów dłużnych (Pincius i Rajgopal 2002, s. 127-160),

- kształtowania wyniku finansowego w drodze przejęć lub zbywania jednostek zależnych.

Tabela 1. Wybrane definicje zarządzania zyskiem typu rzeczowego (realnego) spotykane w światowej literaturze przedmiotu

\begin{tabular}{|l|l|}
\hline \multicolumn{1}{|c|}{ Autor } & \multicolumn{1}{c|}{ Definicja } \\
\hline $\begin{array}{l}\text { K. Schipper } \\
\text { (1989, s. 92) }\end{array}$ & $\begin{array}{l}\text { Realne zarządzanie zyskiem odnosi się do czasowej synchronizacji } \\
\text { realizowanych działań inwestycyjnych lub finansowych, która wpły- } \\
\text { nie na zmianę raportowanego wyniku finansowego bądź podzbioru } \\
\text { czynników go kształtujących }\end{array}$ \\
\hline $\begin{array}{l}\text { R. Ewert, A. Wagenhofer } \\
\text { (2005, s. 1104) }\end{array}$ & $\begin{array}{l}\text { Realne zarządzanie zyskiem ma miejsce, gdy menedżerowie podej- } \\
\text { mują transakcje nieefektywne z punktu widzenia firmy, ale generu- } \\
\text { jące pożądany poziom zysku lub straty w bieżącym okresie }\end{array}$ \\
\hline $\begin{array}{l}\text { S. Roychowdhury } \\
\text { (2006, s. 367) }\end{array}$ & $\begin{array}{l}\text { Działania z zakresu realnego zarządzania zyskiem znajdują swoje } \\
\text { odzwierciedlenie w odchodzeniu od regularnych i typowych praktyk } \\
\text { podejmowanych w ramach prowadzonej działalności podstawowej } \\
\text { przedsiębiorstwa, zaś główną motywacją skłaniającą menedżerów } \\
\text { do ich implementacji jest próba przekonania interesariuszy jedno- } \\
\text { stki, że cele finansowe zostały osiągnięte w toku zwykłych operacji } \\
\text { gospodarczych }\end{array}$ \\
\hline $\begin{array}{l}\text { S. Wang, J.M. D’Souza } \\
\text { (2006, s. 3-5) }\end{array}$ & $\begin{array}{l}\text { dziłalności firmy i może zagrozić konkurencyjności przedsiębior- } \\
\text { stwa w długim okresie }\end{array}$ \\
\hline $\begin{array}{l}\text { A. Vladu } \\
\text { (2015, s. 411) }\end{array}$ & $\begin{array}{l}\text { Realne zarządzanie zyskiem obejmuje ,czasowe zarządzanie” oraz } \\
\text { strukturyzację realizowanych działań operacyjnych, inwestycyjnych } \\
\text { i finansowych w celu wpłynęcia na wartość raportowanych wyni- } \\
\text { ków w określonym, zamierzonym kierunku }\end{array}$ \\
\hline $\begin{array}{l}\text { X. Deng, S.E. Ong } \\
\text { (2018, s. 411) }\end{array}$ & $\begin{array}{l}\text { Realne zarządzanie zyskiem to działania operacyjne kierownictwa } \\
\text { mające na celu zmianę raportowanego wyniku finansowego w okre- } \\
\text { slonym kierunku. Rezultaty te są osiągane poprzez nadprodukcję } \\
\text { (w celu obniżenia kosztów własnych sprzedaży) lub ograniczenie } \\
\text { kosztów uznaniowych w celu poprawy raportowanych zysków. } \\
\text { Innymi słowy, jest to całokształt działań kierowniczych, które } \\
\text { odbiegają od normalnych praktyk biznesowych i mają niekorzystne } \\
\text { konsekwencje biznesowe }\end{array}$ \\
\hline $\begin{array}{l}\text { Realne zarządzanie zyskiem to działania kadry kierowniczej } \\
\text { nakierowane na ukrywanie prawdziwych wyników firmy w drodze } \\
\text { przedsiębrania prawdziwych operacji gospodarczych }\end{array}$ \\
\hline
\end{tabular}

Źródło: opracowanie własne na podstawie (Schipper 1989, Ewent i Wagenhofer 2005, Roychowdhury 2006, Wang i D’Souza 2006, Valdu 2015, Huang i Sun 2017, Deng i Ong 2018). 
Wyeksponowanie powyższych spostrzeżeń i wniosków pozwala podkreślić mnogość potencjalnych działań przedsiębiorstwa w obszarze REM. Wykorzystywane metody i techniki rzeczowego oddziaływania na wynik finansowy mają zróżnicowaną skuteczność w intencjonalnym kreowaniu raportowanego zysku (straty) w przedsiębiorstwie.

\section{Modele Roychowdhury'ego i Gunny jako narzędzia estymacji REM}

Metodologia szacowania skali REM stworzona przez S. Roychowdhury'ego (2006) zakłada możliwość estymacji praktyk rzeczowego kształtowania wyniku finansowego na podstawie następujących miar: wskaźnik dyskrecjonalnych operacyjnych przepływów pieniężnych (abnormal cash flow from operations; discretionary cash flow from operations $-O C F_{\text {disc }}$, wskaźnik dyskrecjonalnych kosztów produkcji (abnornal cost of good sold and changes in inventory; discretionary production - $P R O D_{\text {disc }}$ ) oraz wskaźnik dyskrecjonalnych kosztów uznaniowych (abnormal, discretionary expenditures - DISX ${ }_{\text {disc }}$ ). Wartości ww. współczynników są możliwe do obliczenia z zastosowaniem zróżnicowanych modeli regresji, których formuły analityczne opierają się przede wszystkim na wartości generowanych przychodów ze sprzedaży (zob. tabela 2). Przypisanie przychodom z podstawowej działalności operacyjnej przedsiębiorstwa charakteru zmiennej objaśniającej jest uzasadnionym zabiegiem metodologicznym z uwagi na to, że o jej wielkości i charakterze przekształceń decydują zmiany: popytu rynkowego, wielkości i jakości oferowanych i sprzedawanych wyrobów, kosztów produkcji i sprzedaży wyrobów, rentowności sprzedaży itp. W modelach tych przyjęto, że produkcja jest środkiem realizacji celów finansowych podmiotów gospodarczych i powinna być podporządkowana możliwościom sprzedaży, zaś standing finansowy jednostki jest w dużej mierze kształtowany przez stopień dopasowania programu produkcyjnego do zapotrzebowania rynkowego (Comporek 2020, s. 87). Dodatkowo, w każdym z analizowanych przypadków poziom REM prognozowany jest na podstawie wartości składnika resztowego danego modelu regresyjnego, przy czym z analitycznego punktu widzenia należy podkreślić, że o skali implementowanych praktyk REM w jednostce gospodarczej świadczyć będą:

- odchylenia in minus wartości dyskrecjonalnych operacyjnych przepływów pieniężnych od zera (0) - współczynnik $O C F_{\text {disc }}$ obrazuje zakres potencjalnych manipulacji wolumenem sprzedaży i odnosi się do decyzji menedżerów dotyczących tymczasowego zwiększania obrotu poprzez łagodzenie polityki udzielanych kredytów handlowych oraz oferowanie wyjątkowo korzystnych upustów cenowych. W konsekwencji zakłada się, że tego typu działania wpłyną na intensy- 
fikację poziomu należności oraz jednoczesny spadek poziomu wykazywanych operacyjnych przepływów pieniężnych (w stosunku do poziomu, który faktycznie mógłby zostać osiągnięty w toku „,normalnych” działań gospodarczych) (Ferentinou i Anagnostopoulou 2016, s. 2-23);

- dodatnie odchylenia współczynnika $P R O D_{\text {disc }}$ od zera (0) - wskaźnik dyskrecjonalnych kosztów produkcji $\left(P R O D_{\text {disc }}\right)$ świadczy o implementowanej skali nadprodukcji w jednostce gospodarczej i odzwierciedla dążenia kadry kierowniczej do zwiększenia liczby wytworzonych produktów do poziomu przekraczającego oczekiwany popyt na rynku, dzięki czemu możliwe stanie się rozłożenie kosztów stałych produkcji na większą liczbę wytworzonych dóbr, co w konsekwencji skutkować będzie obniżeniem kosztu jednostkowego sprzedanych produktów;

- odchylenia in minus współczynnika $D I S X_{\text {disc }}$ od zera (0) - w tradycyjnym podejściu koszty uznaniowe uwzględniają: koszty sprzedaży, koszty ogólnego zarządu (a zatem koszty okresu) oraz nakłady na badania i rozwój, zaś ich „nienaturalna" minimalizacja w danym okresie obrachunkowym może być postrzegana jako jeden z wymiarów praktyk REM. Ponieważ w wielu krajach wartość nakładów na sferę $B+R$ nie jest wykazywana w sprawozdaniach finansowych wprost (zwykle ma to miejsce w dodatkowych informacjach i objaśnieniach dla sprawozdań finansowych $)^{1}$, w literaturze przedmiotu spotkać się można z wydzielaniem odrębnych modeli służących do szacowania REM z perspektywy poszczególnych pozycji wchodzących w skład kosztów uznaniowych (zob. tabela 2).

Tabela 2. Formuły obliczeniowe służące do szacowania skali $R E M$ według metodologii S. Roychowdhury'ego

\begin{tabular}{|l|}
\hline \multicolumn{1}{|c|}{ Miara, formuła obliczeniowa } \\
\hline Współczynnik dyskrecjonalnych operacyjnych przepływów pieniężnych $-O C F_{\text {disc }}:$ \\
$\frac{O C F_{t}}{T A_{t-1}}=\alpha_{1}\left(\frac{1}{T A_{t-1}}\right)+\alpha_{2}\left(\frac{R E V_{t}}{T A_{t-1}}\right)+\alpha_{3}\left(\frac{\Delta R E V_{t}}{T A_{t-1}}\right)+\varepsilon_{t}^{O C F}$ \\
gdzie: \\
$\widehat{\varepsilon_{t}^{O C F}}=O C F_{\text {disc }, t}$ \\
\hline
\end{tabular}

${ }^{1}$ W przeciwieństwie do sprawozdań finansowych przygotowywanych zgodnie z założeniami US GAAP, w których koszty związane z badaniami i rozwojem są jedną z głównych pozycji kosztów operacyjnych ewidencjonowanych w rachunku wyników. Z problemem tym stykają się liczni badacze, którzy nie opierają się na wykorzystaniu bazy danych COMPUSTAT. Przykładowo, A.C. Ferentinou i S.C. Anagnostopoulou (2016), przeprowadzając swoje badania w oparciu o bazę Worlsdcope, analizę kosztów uznaniowych sprowadziły jedynie do badań nad kształtowaniem kosztów ogólnego zarządu i kosztów sprzedaży. 
cd. tabeli 2

\section{Miara, formuła obliczeniowa}

Współczynnik dyskrecjonalnych kosztów produkcji - $P R O D_{\text {disc }}$ :

$\frac{P R O D_{t}}{T A_{t-1}}=\alpha_{0}+\alpha_{1}\left(\frac{1}{T A_{t-1}}\right)+\alpha_{2}\left(\frac{R E V_{t}}{T A_{t-1}}\right)+\alpha_{3}\left(\frac{\Delta R E V_{t}}{T A_{t-1}}\right)+\alpha_{4}\left(\frac{\Delta R E V_{t-1}}{T A_{t-1}}\right)+\varepsilon_{t}^{P R O D}$

gdzie:

$\widehat{\varepsilon_{t}^{P R O D}}=P R O D_{\text {disc }, t}$

Współczynnik dyskrecjonalnych kosztów uznaniowych - DISX $X_{\text {disc }}$ oraz miary wydzielane na jego podstawie, tj.: współczynnik dyskrecjonalnych kosztów ogólnego zarządu i kosztów sprzedaży $-S G \& A_{d i s c}$ oraz współczynnik dyskrecjonalnych nakładów na badania i rozwój $-R \& D_{\text {disc }}$ :

$\frac{D I S X_{t}}{T A_{t-1}}=\alpha_{1}\left(\frac{1}{T A_{t-1}}\right)+\alpha_{2}\left(\frac{R E V_{t-1}}{T A_{t-1}}\right)+\varepsilon_{t}^{D I S X}$

gdzie:

$\widehat{\varepsilon_{t}^{D I S X}}=D I S X_{\text {disc }, t}$

Jednocześnie, za (Srivastava 2019), na podstawie powyższych założeń możliwe staje się wyodrębnienie:

$\frac{S G \& A_{t}}{T A_{t-1}}=\alpha_{1}\left(\frac{1}{T A_{t-1}}\right)+\alpha_{2}\left(\frac{R E V_{t-1}}{T A_{t-1}}\right)+\varepsilon_{t}^{S G \& A}$

gdzie:

$\widehat{\varepsilon_{t}^{S G \& A}}=S G \& A_{\text {disc }, t}$

jak również:

$\frac{R \& D_{t}}{T A_{t-1}}=\alpha_{1}\left(\frac{1}{T A_{t-1}}\right)+\alpha_{2}\left(\frac{R E V_{t-1}}{T A_{t-1}}\right)+\varepsilon_{t}^{R \& D}$

gdzie:

$\widehat{\varepsilon_{t}^{R \& D}}=R \& D_{\text {disc }, t}$

Objaśnienia: $O C F_{t}$ - wartość operacyjnych przepływów pieniężnych w roku $t ; O C F_{d i s c, t}-$ współczynnik dyskrecjonalnych operacyjnych przepływów pieniężnych w roku $t$; $P R O D_{t}$ - wartość kosztów produkcji w roku $t ; P R O D_{d i s c, t}$ - współczynnik dyskrecjonalnych kosztów produkcji w roku $t$; $D I S X_{t}$ - wartość kosztów uznaniowych w roku $t$; DISX $X_{\text {disc, },}$ - współczynnik dyskrecjonalnych kosztów uznaniowych w roku $t ; S G \& A_{t}$ - wartość kosztów ogólnego zarządu i kosztów sprzedaży w roku $t$; $S G \& A_{\text {disc }}$ - współczynnik dyskrecjonalnych kosztów zarządu i kosztów sprzedaży w roku $t ; R \& D_{t}-$ wartość nakładów na $\mathrm{B}+\mathrm{R}$ w roku $t ; R \& D_{\text {disc }}$ - współczynnik dyskrecjonalnych nakładów na $\mathrm{B}+\mathrm{R}$ w roku $t ; T A_{t}$ - wartość aktywów całkowitych na koniec roku $t ; R E V_{t}$ - wartość przychodów ze sprzedaży w roku $t ; \alpha_{i}, i=0,1, \ldots, k$ - parametry modelu regresji; $\frac{\widehat{\varepsilon_{t}^{O C F}}}{t}-$ reszta $\mathrm{z}$ modelu regresji równa dyskrecjonalnym operacyjnym przepływom pieniężnym; $\widehat{\varepsilon_{t}^{P R O D}}$ - reszta z modelu regresji równa dys-

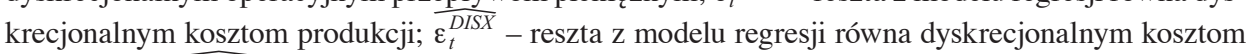
uznaniowym; $\widehat{\varepsilon_{t}^{S G \& A}}$ - reszta z modelu regresji równa dyskrecjonalnym kosztom zarządu i kosztom sprzedaży; $\overline{\varepsilon_{t}^{R \& D}}$ - reszta $\mathrm{z}$ modelu regresji równa dyskrecjonalnym nakładom na $\mathrm{B}+\mathrm{R}$.

Źródło: opracowanie własne na podstawie (Roychowdhury 2006, Srivastava 2019). 
Z kolei K.A. Gunny (2010) opracowała formuły analityczne pomocne do szacowania skali procesów $R E M$ w sferach operacyjnej i pozaoperacyjnej działalności jednostki gospodarczej. Wyznaczając cztery modele ekonometryczne służące do oszacowania: wskaźnika normalnego poziomu nakładów na badania i rozwój (the normal level of $R \& D$ expense), wskaźnika normalnego poziomu kosztów sprzedaży i kosztów ogólnego zarządu (the normal level of $S G \& A$ ), wskaźnika normalnego poziomu dochodów ze sprzedaży aktywów (the normal level of gain on asset sales) oraz wskaźnika normalnego poziomu kosztów produkcji (the normal level of production cost) przyjęła, że o skali REM świadczyć będą różnice zachodzące między wartościami teoretycznymi a empirycznymi poszczególnych zmiennych endogenicznych uwzględnianych w analizach regresji (zob. tabela 3). Należy zauważyć, że w formułach obliczeniowych wspomnianych modeli autorka zawarła szersze spektrum zmiennych egzogenicznych, odnoszących się zarówno do poziomu generowanych przychodów ze sprzedaży, jak i miar ilustrujących: poziom kapitału intelektualnego w jednostce (wskaźnik $Q$-Tobina), wartość rynkową jednostki, poziom dostępnych środków na inwestycje ${ }^{2}$, przychody ze sprzedaży rzeczowych aktywów trwałych czy też zyski ze zbycia inwestycji długoterminowych. $\mathrm{Z}$ interpretacyjnego punktu widzenia o skali działań $R E M$ świadczyć będą:

- odchylenia in minus od zera (0) wartości współczynnika dyskrecjonalnych nakładów na badania i rozwój $\left(R \& D_{\text {disc }}\right)$;

- ujemne odchylenia wartości dyskrecjonalnych kosztów ogólnego zarządu oraz kosztów sprzedaży $\left(S G \& A_{\text {disc }}\right)$ od zera $(0)$;

- dodatnie odchylenia dyskrecjonalnych kosztów produkcji $P R O D_{\text {disc }}$ od zera (0) - co może odzwierciedlać dążenia do „sztucznego” wzrostu sprzedaży w danym okresie obrachunkowym kosztem realizowanego poziomu zyskowności w przyszłości. Z drugiej zaś strony D. Herrmann, T. Inoue i W.B. Thomas (2003) udowodnili, że o skali $R E M$ w sferze produkcyjnej może świadczyć również chęć obniżania kosztów sprzedanych produktów, materiałów i towarów;

- czasowe zarządzanie transakcjami sprzedaży aktywów $\left(G a i n A_{d i s c}\right)$ - polegające na dokonywaniu operacji gospodarczych w takim czasie, który nie odpowiada rzeczywistym potrzebom gospodarczym, i mające miejsce wówczas, gdy powstaną korzystne warunki do uzyskania określonego poziomu wyniku finansowego.

${ }^{2}$ Poziom dostępnych środków na inwestycje obliczany jest jako wartość wyniku z działalności operacyjnej (bez uwzględnienia pozycji nadzwyczajnych) powiększona o amortyzację i poniesione nakłady na $\mathrm{B}+\mathrm{R} w$ danym okresie rozrachunkowym. 
Tabela 3. Formuły obliczeniowe służące do szacowania skali REM według metodologii K.A. Gunny

\begin{tabular}{|c|}
\hline Miara, formuła obliczeniowa \\
\hline $\begin{array}{l}\text { Współczynnik dyskrecjonalnych nakładów na badania i rozwój }-R \& D_{\text {disc }} \text { : } \\
\frac{R \& D_{t}}{T A_{t-1}}=\alpha_{0}+\alpha_{1}\left(\frac{1}{T A_{t-1}}\right)+\alpha_{2} M V_{t}+\alpha_{3} Q_{t}+\alpha_{4}\left(\frac{I N T F_{t}}{T A_{t-1}}\right)+\alpha_{5}\left(\frac{R \& D_{t-1}}{T A_{t-1}}\right)+\varepsilon_{t}^{R \& D} \\
\text { gdzie: } \\
\widehat{\varepsilon_{t}^{R \& D}}=R \& D_{\text {disc }, t}\end{array}$ \\
\hline $\begin{array}{l}\text { Współczynnik dyskrecjonalnych kosztów ogólnego zarządu i kosztów sprzedaży }-S G \& A_{\text {disc }} \text { : } \\
\frac{S G \& A_{t}}{T A_{t-1}}=\alpha_{0}+\alpha_{1}\left(\frac{1}{T A_{t-1}}\right)+\alpha_{2} M V_{t}+\alpha_{3} Q_{t}+\alpha_{4}\left(\frac{I N T F_{t}}{T A_{t-1}}\right)+\alpha_{5}\left(\frac{\Delta R E V_{t}}{T A_{t-1}}\right)+\alpha_{6}\left(\frac{\Delta R E V_{t}}{T A_{t-1}} \cdot D D\right)+\varepsilon_{t}^{S G \& A} \\
\text { gdzie: } \\
\overline{\varepsilon_{t}^{S G \& A}}=S G \& A_{\text {disc }, t}\end{array}$ \\
\hline $\begin{array}{l}\text { Współczynnik dyskrecjonalnych zysków ze sprzedaży aktywów }- \text { Gain }_{\text {disc }} \text { : } \\
\frac{\text { GAINA }_{t}}{T A_{t-1}}=\alpha_{0}+\alpha_{1}\left(\frac{1}{T A_{t-1}}\right)+\alpha_{2} M V_{t}+\alpha_{3} Q_{t}+\alpha_{4}\left(\frac{I N T_{t}}{T A_{t-1}}\right)+\alpha_{5}\left(\frac{A R E V_{t}}{T A_{t-1}}\right)+\alpha_{6}\left(\frac{I R E V_{t}}{T A_{t-1}}\right)+\varepsilon_{t}^{\text {GainA }} \\
\text { gdzie: } \\
\widehat{\varepsilon_{t}^{\text {GainA }}}=\text { GainA }_{\text {disc }, t}\end{array}$ \\
\hline $\begin{array}{l}\text { Współczynnik dyskrecjonalnych kosztów produkcji }-P R O D_{\text {disc }} \text { : } \\
\frac{P R O D_{t}}{T A_{t-1}}=\alpha_{0}+\alpha_{1}\left(\frac{1}{T A_{t-1}}\right)+\alpha_{2} M V_{t}+\alpha_{3} Q_{t}+\alpha_{4}\left(\frac{R E V_{t}}{T A_{t-1}}\right)+\alpha_{5}\left(\frac{\Delta R E V_{t}}{T A_{t-1}}\right)+\alpha_{6}\left(\frac{\Delta R E V_{t-1}}{T A_{t-1}}\right)+\varepsilon_{t}^{P R O D} \\
\frac{\text { gdzie: }}{\widehat{\varepsilon_{t}^{P R O D}}}=P R O D_{\text {disc }, t}\end{array}$ \\
\hline
\end{tabular}

Objaśnienia: $M V_{t}-\operatorname{logarytm}$ naturalny wartości rynkowej przedsiębiorstwa w roku $t ; Q_{t}-$ wartość wskaźnika $Q$-Tobina w roku $t ; I N T F_{t}$ - wartość środków wewnętrznych na inwestycje w roku $t$; $A R E V_{t}$ - wartość przychodów ze zbycia aktywów w roku $t ; I R E V_{t}$ - wartość przychodów ze zbycia inwestycji w roku $t ; D D$ - zmienna zerojedynkowa (równa 1 - gdy nastąpił spadek przychodów ze sprzedaży między okresami $t-1$ i $t$, równa $0-$ w pozostałych przypadkach); Gain $A_{t}-$ zysk ze sprzedaży aktywów w roku $t$; GainA $A_{\text {disc, },}$ - współczynnik dyskrecjonalnych zysków ze sprzedaży aktywów w roku $t ; \overline{\varepsilon_{t}^{\text {GainA }}}$ - reszta z modelu regresji równa zyskom ze sprzedaży aktywów, pozostałe oznaczenia - jak w objaśnieniach do tabeli 2 .

Źródło: opracowanie własne na podstawie (Gunny 2010). 


\section{Wyniki badań empirycznych}

Zaprezentowane wyniki badań empirycznych zawierają rezultaty analityczne odnoszące się do dwóch podstawowych kwestii poznawczych. Pierwszą z nich jest ocena dopasowania analizowanych modeli regresyjnych $R E M$ do danych empirycznych, drugą zaś - analiza zróżnicowania obliczonych wartości dyskrecjonalnych kosztów produkcji $\left(P R O D_{\text {disc }}\right)$ oraz kosztów sprzedaży i ogólnego zarządu $\left(S G \& A_{d i s c}\right)$ w badanych spółkach giełdowych. Wskaźnik $Q$-Tobina, stanowiący jedną ze zmiennych egzogenicznych w modelach Gunny, został wyznaczony według formuły Chunga i Pruitta (1994):

$$
Q \text {-Tobin }=\frac{M V C S+B V P S+B V L T D+B V I N V+B V C L-B V C A}{B V T A},
$$

gdzie:

$Q$-Tobin - wartość współczynnika $Q$-Tobina w roku $t$,

MVCS - wartość rynkowa akcji zwykłych w roku $t$,

$B V P S$ - wartość księgowa akcji uprzywilejowanych w roku $t$,

$B V L T D$ - wartość księgowa zobowiązań długoterminowych w roku $t$,

$B V I N V$ - wartość księgowa zapasów w roku $t$,

$B V C L$ - wartość księgowa zobowiązań krótkoterminowych w roku $t$,

$B V C A$ - wartość księgowa aktywów obrotowych w roku $t$,

$B V T A$ - wartość księgowa wszystkich aktywów w roku $t$.

Na podstawie zaprezentowanych w tabeli 4 wyników badań empirycznych można stwierdzić, że procent zmienności zmiennych endogenicznych $P R O D$ i $S G \& A$ objaśnianych przez rozpatrywane modele ekonometryczne wyraźnie różnicował się w analizowanej grupie przedsiębiorstw. Zdecydowanie wyższe wartości skorygowanych współczynników determinacji $R^{2}$ (wynoszące odpowiednio: 93,2\% w modelu opracowanym przez S. Roychowdhury'ego i 93,4\% w modelu autorstwa K.A. Gunny) uzyskano przy ocenie zmienności kosztów produkcji $P R O D$. Z kolei modelem o najmniejszym stopniu dopasowania do danych empirycznych okazał się model Gunny, służący do estymacji normalnego poziomu kosztów sprzedaży i kosztów ogólnego zarządu $S G \& A$ (wartość dopasowanego współczynnika determinacji $R^{2}$ wyniosła w tym przypadku $12,6 \%$ ). Warto podkreślić, że przeprowadzone badania nie wykazały istotnych korelacji między wartościami zmiennych endogenicznych $P R O D$ i $S G \& A$ oraz obliczonymi współczynnikami $Q$-Tobina. Z kolei parametr stojący przy zmiennej egzogenicznej obrazującej wartość rynkową podmiotu gospodarczego $(M V)$ okazał się istotny statystycznie jedynie w odniesieniu do szacowanych nieuznaniowych kosztów produkcji $P R O D$, estymowanych według formuły analitycznej K.A. Gunny. 
Tabela 4. Ocena parametrów strukturalnych oraz stopnia dopasowania modeli służących do estymacji REM w publicznych spółkach giełdowych sektora „,budownictwo”

\begin{tabular}{|l|c|c|c|c|}
\hline \multirow{2}{*}{\begin{tabular}{l}
\multirow{2}{*}{ Parametry/ } \\
\cline { 2 - 5 }
\end{tabular}} & \multicolumn{4}{|c|}{ Zmienne endogeniczne } \\
\cline { 2 - 5 } & metodologia S. Roychowdhury'ego & \multicolumn{2}{c|}{ metodologia K.A. Gunny } \\
\cline { 2 - 5 } & $P R O D$ & $S G \& A$ & $P R O D$ & $S G \& A$ \\
\hline $1 / T A_{t-1}$ & $\mathbf{- 0 , 1 0 4}$ & - & 0,175 & 0,038 \\
\hline$M V_{t}$ & $\mathbf{- 3 2 6 7 , 1 4 6}$ & $\mathbf{2 2 4 2 , 8 6 7}$ & $\mathbf{- 4 3 4 6 , 9 5 4}$ & $\mathbf{2 4 0 5 , 9 5 2}$ \\
\hline$Q_{t}$ & - & - & $-0,023$ & 0,004 \\
\hline$I N T F_{t}$ & - & - & $-0,004$ & 0,002 \\
\hline$R E V_{t} / T A_{t-1}$ & - & - & - & $\mathbf{0 , 2 7 1}$ \\
\hline$R E V_{t-1} / T A_{t-1}$ & $\mathbf{0 , 9 7 7}$ & - & $\mathbf{0 , 9 8 6}$ & $-0,021$ \\
\hline$\Delta R E V_{t} / T A_{t-1}$ & - & $\mathbf{0 , 0 7 7}$ & - & - \\
\hline$\left(\Delta R E V_{t} / T A_{t-1}\right) \cdot D D$ & $-\mathbf{0 , 0 4 9}$ & - & $-0,046$ & - \\
\hline$\Delta R E V_{t-1} / T A_{t-1}$ & $-0,013$ & - & - & 0,060 \\
\hline Dopasowany $R^{2}$ & 0,932 & 0,567 & $-0,006$ & - \\
\hline Błąd standardowy & 0,160 & 0,098 & 0,934 & 0,126 \\
\hline$F$ & 982,880 & 191,133 & 675,353 & 0,092 \\
\hline Istotność $F$ & 0,000 & 0,000 & 0,000 & 0,000 \\
\hline
\end{tabular}

Uwaga: czcionką pogrubioną oznaczono parametry istotne statystycznie przy przyjętym poziomie istotności równym 0,05 .

Źródło: opracowanie własne.

Wyniki badań empirycznych przedstawione w tabeli 5 wskazują, że wartości dyskrecjonalnych kosztów produkcji $P R O D_{\text {disc }}$ wyodrębniane za pomocą obu rozpatrywanych modeli odznaczają się niemal pełnym stopniem skorelowania $(0,983)$. Może to oznaczać, że przyjęty sposób szacowania nieuznaniowych kosztów produkcji $P R O D$ w analizowanej populacji nie będzie znacząco wpływał na estymowane wartości dyskrecjonalnych kosztów produkcji $P R O D_{\text {disc }}$. Podobnie, bardzo wysokim stopniem skorelowania (wynoszącym 0,861 ) cechują się wartości dyskrecjonalnych kosztów sprzedaży i kosztów ogólnego zarządu $S G \& A_{\text {disc }}$ wyodrębniane za pomocą formuł analitycznych S. Roychowdhury'ego i K.A. Gunny. Warto podkreślić, że zależności między zmiennymi $P R O D_{d i s c}$ oraz $S G \& A_{\text {disc }}$ przybierają postać silnych, negatywnych związków opisanych za pomocą współczynnika korelacji liniowej Pearsona w przedziale 51,7- 63,6\%.

Graficzne odzwierciedlenie powyższych spostrzeżeń przedstawiono na rys. 1-4 ukazujących średnie wartości współczynników $P R O D_{\text {disc }}$ oraz $S G \& A_{d i s c}$, obliczone dla poszczególnych spółek poddanych analizie. Rezultaty badań empirycznych 
przedstawione na rys. 1 i 2 ukazują bowiem, że w rozpatrywanym okresie odniesienia, tj. w latach 2006-2018, w większości badanych przedsiębiorstw średnie 12-letnie wartości miar $P R O D_{\text {disc }}$ oraz $S G \& A_{d i s c}$, ekstraktowane za pomocą metodologii S. Roychowdhury’ego i K.A. Gunny były do siebie zbliżone. Tylko w nielicznych przypadkach (spółki: Atrem SA i Mirbud SA - dla $P R O D_{\text {disc }}$ oraz spółki: Lentex SA, Remak SA, Ropczyce SA i Ulma SA - dla $S G \& A_{\text {disc }}$ ) wartości opisywanych miar REM przybierały odwrotne (tj. dodatnie i ujemne) wartości w zależności od przyjętej formuły analitycznej służącej do ich wyznaczania.

Tabela 5. Zależności między poszczególnymi współczynnikami $R E M$ w publicznych spółkach giełdowych sektora ,budownictwo”

\begin{tabular}{|l|c|c|c|c|c|}
\hline \multicolumn{2}{|c|}{$\begin{array}{c}\text { Wartości współczynnika korelacji } \\
\text { liniowej Pearsona }\end{array}$} & \multicolumn{2}{c|}{$\begin{array}{c}\text { Metodologia } \\
\text { S. Roychowdhury'ego }\end{array}$} & \multicolumn{2}{c|}{$\begin{array}{c}\text { Metodologia } \\
\text { K.A. Gunny }\end{array}$} \\
\cline { 2 - 6 } & $P R O D_{\text {disc }}$ & $S G \& A_{\text {disc }}$ & $P R O D_{\text {disc }}$ & $S G \& A_{\text {disc }}$ \\
\hline $\begin{array}{l}\text { Metodologia } \\
\text { S. Roychowdhury'ego }\end{array}$ & $P R O D_{\text {disc }}$ & 1 & $-0,636$ & 0,983 & $-0,517$ \\
\cline { 2 - 6 } & $S G \& A_{\text {disc }}$ & $-0,636$ & 1 & $-0,625$ & 0,861 \\
\hline $\begin{array}{l}\text { Metodologia } \\
\text { K.A. Gunny }\end{array}$ & $P R O D_{\text {disc }}$ & 0,983 & $-0,625$ & 1 & $-0,532$ \\
\cline { 2 - 6 } & $S G \& A_{\text {disc }}$ & $-0,517$ & 0,861 & $-0,532$ & 1 \\
\hline
\end{tabular}

Źródło: opracowanie własne.

Zakładając, zgodnie ze spostrzeżeniami S. Roychowdhury’ego, że o skali potencjalnej manipulacji w obszarze REM mogą świadczyć dodatnie odchylenia współczynnika $P R O D_{\text {disc }}$ od zera, podkreślić należy, że o ponadprzeciętnej skali praktyk z zakresu rzeczowego zarządzania zyskiem można mówić w kontekście takich spółek, jak: Mostostal Warszawa SA, Polimex Mostostal SA czy Trakcja SA (zob. rys. 1). Dla tych podmiotów bowiem zanotowano najwyższe średnie 12-letnie wartości współczynników uznaniowych kosztów produkcji $P R O D_{d i s c}$. Z drugiej zaś strony uwagę zwracają bardzo wysokie, negatywne średnie wartości wskaźnika $P R O D_{\text {disc }}$, obliczone dla spółek Selena FM SA oraz Śnieżka SA.

Zaprezentowane na rys. 2 średnie 12-letnie wartości dyskrecjonalnych kosztów sprzedaży i kosztów ogólnego zarządu $S G \& A_{\text {disc }}$ świadczą, że w przypadku większości podmiotów poddanych analizie mogą być one postrzegane jako swoiste „lustrzane odbicie” wartości wcześniej opisanych współczynników PROD ${ }_{\text {disc }}$. Dominująca część badanych spółek giełdowych w horyzoncie 2006-2018 wykazywała ujemne średnie wartości wskaźnika $S G \& A_{\text {disc }}$, co może być odbierane jako potencjalna przesłanka do uznania, że manipulowały one wynikiem finansowym za pomocą praktyk REM. Wyraźne odchylenia in plus wartości dyskrecjonalnych kosztów ogólnego zarządu oraz kosztów sprzedaży $\left(S G \& A_{\text {disc }}\right.$ ) od zera zanoto- 
wano w odniesieniu do takich jednostek gospodarczych, jak: Decora SA, Selena FM SA oraz Śnieżka SA.

Pogłębione badania empiryczne nakierowane zostały na uzyskanie odpowiedzi na pytanie, czy skala praktyk z zakresu REM różnicuje się ze względu na osiągane rezultaty działalności przedsiębiorstw. W tym celu zbadano zależności zachodzące między estymowanymi wartościami współczynników $P R O D_{\text {disc }}$ i $S G \& A_{\text {disc }}$ a wypracowanymi wartościami współczynników rentowności netto aktywów $R O A$. Analizowana populacja $(n=290$ obserwacji) podzielona została w oparciu o kwantyle dziesiątego rzędu, stosowane do wyznaczenia rozkładu normalnego zmiennej $R O A$ w badanej grupie przedsiębiorstw. W konsekwencji uzyskano 10 podgrup (składających się z 29 obserwacji) ilustrujących analizowaną zbiorowość z uwagi na osiąganą wartość współczynnika rentowności netto aktywów. Na podstawie rezultatów badań empirycznych przedstawionych na rys. 3 można przypuszczać, że spółki giełdowe operujące w sektorze „budownictwo”, które charakteryzowały się niskimi wartościami współczynników ROA, wykazywały jednocześnie dodatnie wartości dyskrecjonalnych kosztów produkcji $P R O D_{d i s c}$. $\mathrm{Z}$ drugiej zaś strony, przedsiębiorstwa uzyskujące wysokie wartości współczynników $R O A$ odznaczały się ujemnymi wartościami współczynników $P R O D_{\text {disc }}$. W przypadku kształtowania wartości współczynników uznaniowych kosztów sprzedaży i kosztów ogólnego zarządu $S G \& A_{\text {disc }}$ dane zobrazowane na rys. 4 pozwalają na stwierdzenie, że średnie wartości wskaźników $S G \& A_{\text {disc }}$ przybierały zróżnicowaną postać w poszczególnych podgrupach badanej zbiorowości.

Tabela 6. Wyniki testu Manna-Whitneya-Wilcoxona badającego kształtowanie współczynników $R E M$ w spółkach generujących niskie (wysokie) wartości współczynników $R O A$

\begin{tabular}{|c|c|c|c|c|c|c|c|}
\hline Miara REM & $\begin{array}{c}\text { Wartość } \\
\text { ROA }\end{array}$ & $\begin{array}{c}\text { Średnia } \\
\text { ranga }\end{array}$ & $\begin{array}{l}\text { Suma } \\
\text { rang }\end{array}$ & $\begin{array}{c}\text { Test } U \\
\text { Manna- } \\
\text {-Whitneya }\end{array}$ & $\begin{array}{c}\text { Test } W \\
\text { Wilcoxona }\end{array}$ & $Z$ & $\begin{array}{c}\text { Istotność } \\
\text { asympto- } \\
\text { tyczna }\end{array}$ \\
\hline \multirow{2}{*}{$\begin{array}{l}P R O D_{\text {disc }} \\
\text { Roychowdhury }\end{array}$} & niska & 79,45 & 4608,00 & \multirow{2}{*}{467,00} & \multirow{2}{*}{2178,00} & \multirow{2}{*}{$-6,71$} & \multirow{2}{*}{0,000} \\
\hline & wysoka & 37,55 & 2178,00 & & & & \\
\hline \multirow{2}{*}{$\begin{array}{l}P_{\text {ROD }} \\
\text { Gunny }\end{array}$} & niska & 76,90 & 4460,00 & \multirow{2}{*}{615,00} & \multirow{2}{*}{2326,00} & \multirow{2}{*}{$-5,89$} & \multirow{2}{*}{0,000} \\
\hline & wysoka & 40,10 & 2326,00 & & & & \\
\hline \multirow{2}{*}{$\begin{array}{l}S G \& A_{d i s c} \\
\text { Roychowdhury }\end{array}$} & niska & 51,86 & 3008,00 & \multirow{2}{*}{1297,00} & \multirow{2}{*}{3008,00} & \multirow{2}{*}{$-2,13$} & \multirow{2}{*}{$\mathbf{0 , 0 3 4}$} \\
\hline & wysoka & 65,14 & 3778,00 & & & & \\
\hline \multirow{2}{*}{$\begin{array}{l}S G \& A_{d i s c} \\
\text { Gunny }\end{array}$} & niska & 62,78 & 3641,00 & \multirow{2}{*}{1434,00} & \multirow{2}{*}{3145,00} & \multirow{2}{*}{$-1,37$} & \multirow{2}{*}{0,171} \\
\hline & wysoka & 54,22 & 3145,00 & & & & \\
\hline
\end{tabular}

Uwaga: czcionką pogrubioną oznaczono parametry istotne statystycznie przy przyjętym poziomie istotności równym 0,05 .

Źródło: opracowanie własne. 


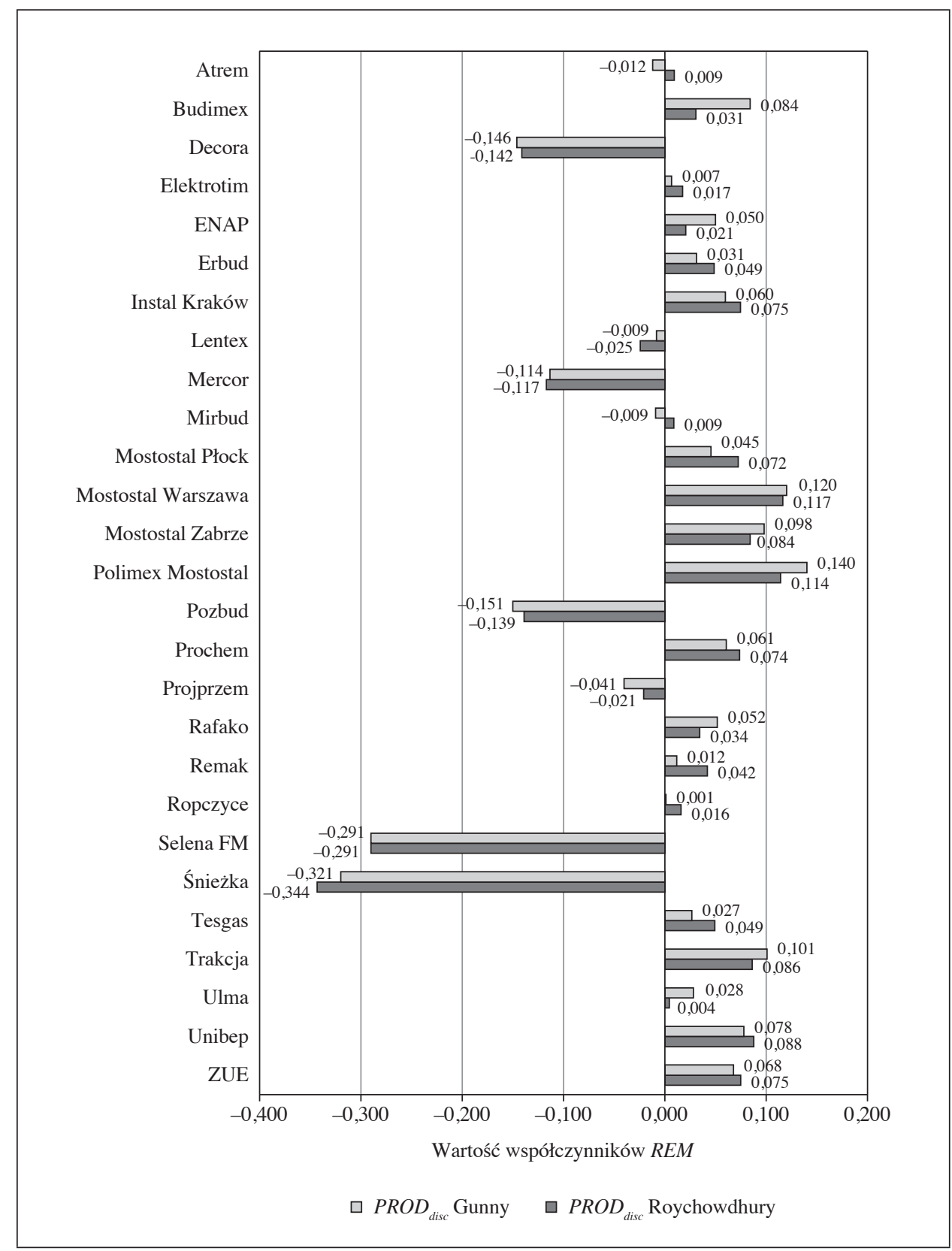

Rys. 1. Średnie 12-letnie wartości współczynników $P R O D_{\text {disc }}$ obliczone dla spółek giełdowych sektora „budownictwo"

Źródło: opracowanie własne. 


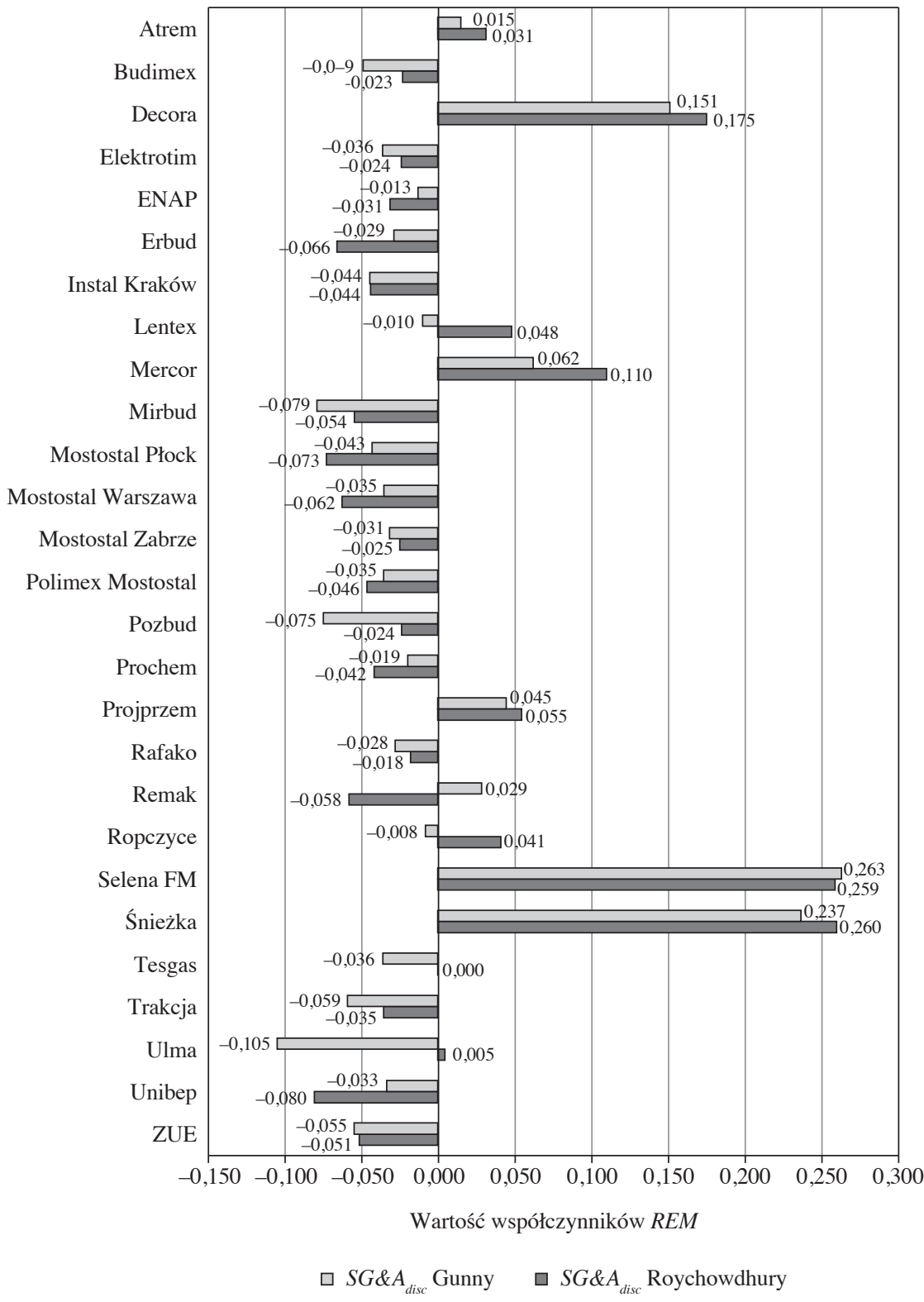

Rys. 2. Średnie 12-letnie wartości współczynników $S G \& A_{\text {disc }}$ obliczone dla spółek giełdowych sektora „budownictwo"

Źródło: opracowanie własne. 


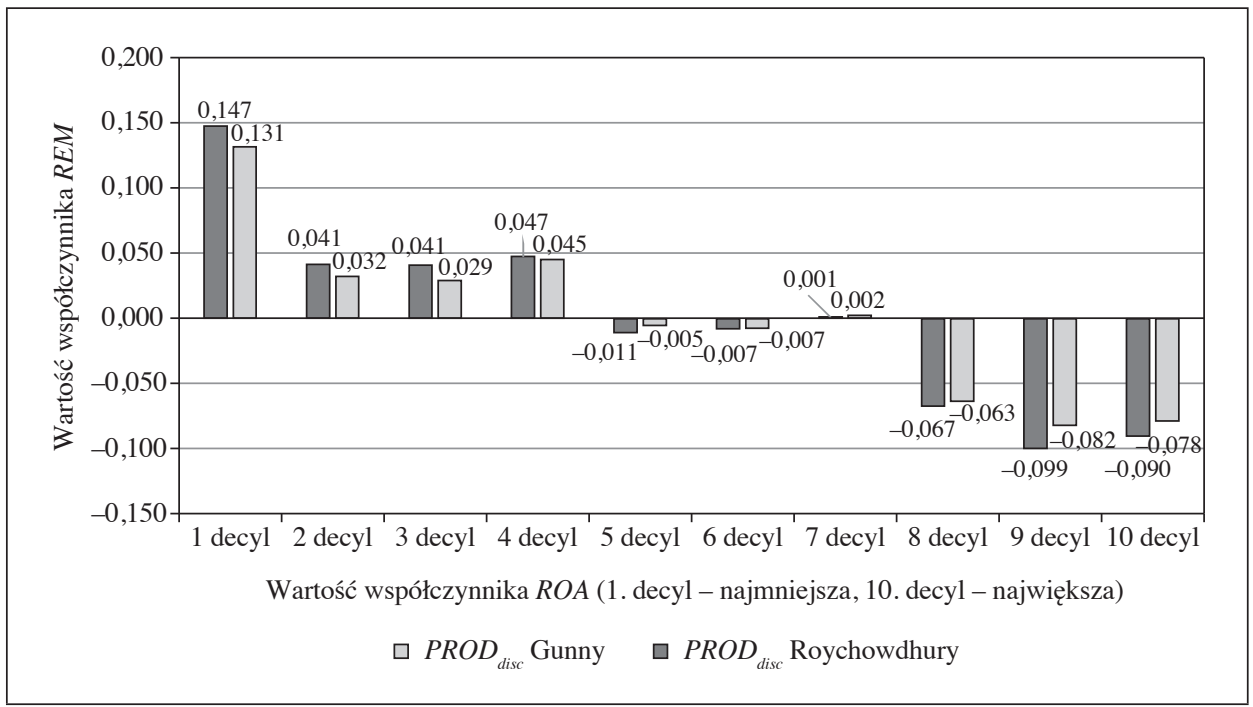

Rys. 3. Średnie wartości współczynnika $P R O D_{\text {disc }}$ w zależności od uzyskiwanych wartości wskaźnika rentowności netto aktywów ROA

Źródło: opracowanie własne.

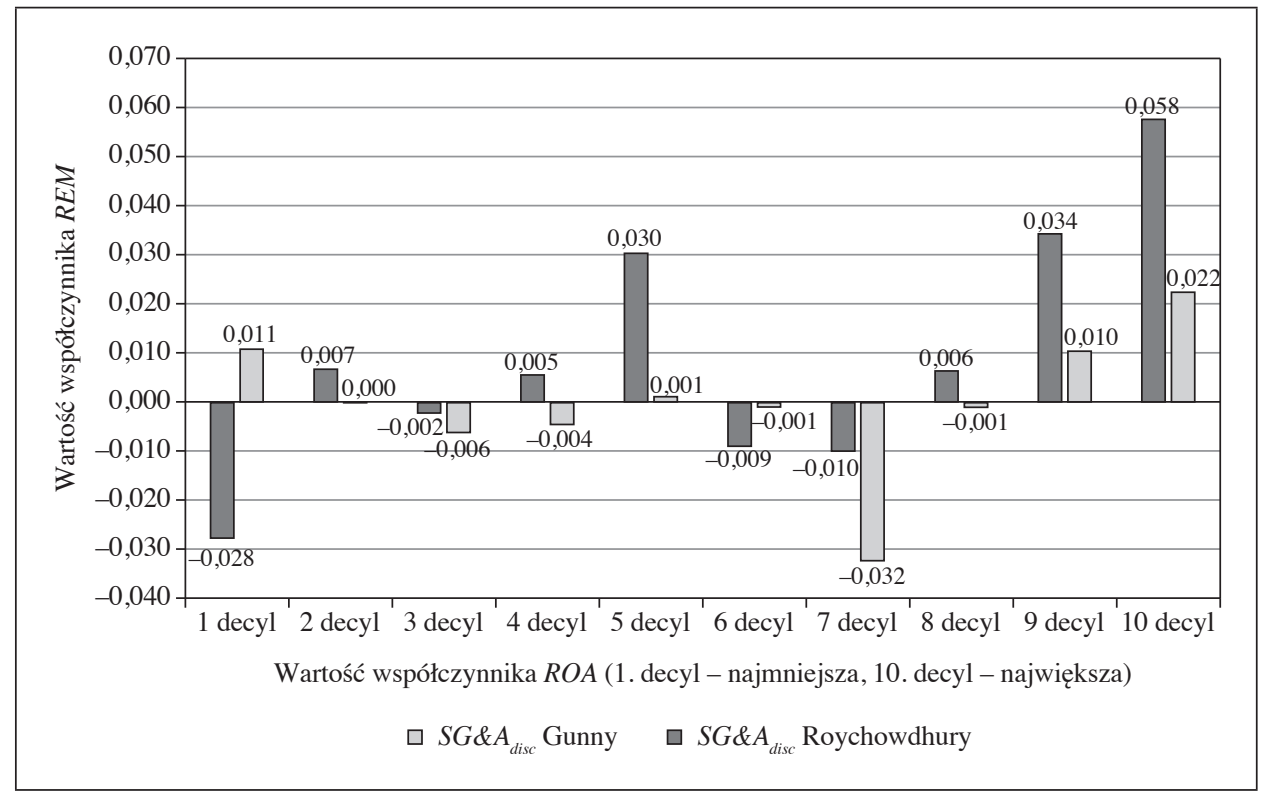

Rys. 4. Średnie wartości współczynnika $S G \& A_{\text {disc }}$ w zależności od uzyskiwanych wartości wskaźnika rentowności netto aktywów $R O A$

Źródło: opracowanie własne. 
Aby jednoznacznie określić, czy wartości współczynników $P R O D_{\text {disc }}$ i $S G \& A_{\text {disc }}$ różnią się w sposób istotny statystycznie w grupie przedsiębiorstw cechujących się niskimi (wysokimi) wartościami rentowności netto aktywów ROA, wykorzystany został dodatkowo nieparametryczny test Manna-Whitneya-Wilcoxona. Służy on do sprawdzenia, czy wartości próbek pobranych z dwóch niezależnych populacji są jednakowo duże. Na podstawie wyników badań empirycznych przedstawionych w tabeli 6 można stwierdzić, że w przypadku współczynników $P R O D_{\text {disc }}$ wyodrębnianych za pomocą obu rozpatrywanych modeli (Roychowdhury'ego i Gunny), jak również współczynników $S G \& A_{\text {disc }}$ ekstraktowanych przy użyciu modelu Roychowdhury'ego, istnieją podstawy do odrzucenia hipotezy zerowej zakładającej brak istotnych statystycznie różnic w rozkładach tych miar w badanych podpopulacjach. Oznacza ta, że spółki z niskimi wartościami współczynnika ROA (zaszeregowane w badaniu do 1 i 2 decyla) cechują się statystycznie wyższymi wartościami uznaniowych kosztów produkcji $P R O D_{\text {disc }}$ i jednocześnie niższymi wartościami wskaźnika $S G \& A_{d i s c}$ (wyznaczanego za pomocą metodologii S. Roychowdhury'ego), aniżeli przedsiębiorstwa uzyskujące wysokie wartości ROA (zakwalifikowane do 9 i 10 decyla).

\section{Zakończenie}

Rzeczowe zarządzanie zyskiem jest jedną z dwóch dominujących strategii intencjonalnego kształtowania wyniku finansowego w przedsiębiorstwie. Ze względu na to, że działania te są o wiele trudniejsze do dostrzeżenia dla poszczególnych grup interesariuszy podmiotu gospodarczego oraz w mniejszym stopniu podlegają kontroli zewnętrznej, również estymacja ich zakresu i kierunków staje się bardziej skomplikowana niż w przypadku księgowego zarządzania zyskiem. Do najczęściej wykorzystywanych narzędzi służących do predykcji praktyk $R E M$ w podmiotach gospodarczych należą modele autorstwa S. Roychowdhury'ego i K.A. Gunny.

Zrealizowane badania empiryczne wykazały, że modele ekonometryczne wykorzystywane do estymacji normalnego poziomu kosztów produkcji $P R O D$ charakteryzują się znacznie wyższym stopniem dopasowania do danych empirycznych aniżeli formuły regresyjne służące do szacowania nieuznaniowego poziomu kosztów sprzedaży i kosztów ogólnego zarządu $S G \& A$. Interesujący jest fakt, że w przypadku współczynników dyskrecjonalnych kosztów produkcji $P R O D_{\text {disc }}$ przyjęty sposób ich ekstrakcji wydaje się nie mieć dużego znaczenia analitycznego. Związki zachodzące między obliczonymi wartościami tych miar (estymowanymi odrębnie za pomocą modelu Roychowdhury'ego i modelu Gunny) cechuje niemal pełny stopień skorelowania (siła związku, mierzona za pomocą współczynnika korelacji liniowej Pearsona, wyniosła 98,3\%). Z perspektywy 
współczynników obrazujących poziom dyskrecjonalnych kosztów sprzedaży i kosztów ogólnego zarządu $S G \& A_{\text {disc }}$ relacja między wartościami tych miar, wyodrębnianymi oddzielnie przy użyciu obu metodologii, wciąż była bardzo silna, lecz zauważalnie niższa (siła związku określona w 86,1\%).

Na podstawie wyników przeprowadzonych badań empirycznych można ponadto stwierdzić, że poziom uznaniowych kosztów produkcji $P R O D_{\text {disc }}$ był W sposób istotny statystycznie związany z generowaną rentownością netto aktywów. Mianowicie, na podstawie testu Manna-Whitneya-Wilcoxona udowodniono, że w badanej populacji spółki wykazujące niskie wartości współczynnika $R O A$ cechowały się wysokimi wartościami współczynnika $P R O D_{\text {disc }}$ (i na odwrót). Może to skłaniać do konkluzji, że w podmiotach tych szerszy zakres implementacji praktyk REM nakierowany był na świadome obniżanie wyniku finansowego w danym okresie sprawozdawczym. Mniej jednoznaczna wydaje się interpretacja powiązań zachodzących między uzyskiwanymi wartościami współczynnika $R O A$ a wartością współczynników $S G \& A_{\text {disc }}$, w publicznych spółkach akcyjnych działających w sektorze „budownictwo”. Wykonane testy statystyczne wykazały wprawdzie, że przedsiębiorstwa mniej rentowne (niskie wartości wskaźnika ROA) cechują niższe wartości wskaźnika $S G \& A_{d i s c}$, uwaga ta dotyczy jednak wyłącznie dyskrecjonalnych kosztów sprzedaży i kosztów ogólnego zarządu $S G \& A_{\text {disc }}$ estymowanych za pomocą formuł Roychowdhury'ego.

Przedstawione wnioski wynikające ze zrealizowanych badań empirycznych mają charakter egzemplifikacyjny. Nie wypełniają one warunku generalizacji i powinny być poszerzone na większą liczbę spółek prowadzących działalność gospodarczą w zróżnicowanych branżach gospodarki. Pozwalają one jednak na zasygnalizowanie ważności i aktualności zagadnień pomiaru REM w przedsiębiorstwach oraz na zwrócenie uwagi na to, że wykorzystywane metody i techniki zarządzania zyskiem mają zróżnicowaną skuteczność w rzeczowym kreowaniu raportowanego zysku (straty).

\section{Literatura}

Bartov E. (1993), The Timing of Asset Sales and Earnings Manipulation, „The Accounting Review", vol. 4, nr 68.

Braam G., Nandy M., Weitzel U., Lodh S. (2015), Accrual-based and Real Earnings Management and Political Connections, „The International Journal of Accounting”, vol. 50, $\mathrm{nr}$ 2, https://doi.org/10.1016/j.intacc.2013.10.009.

Bushee B. (1998), The Influence of Institutional Investors on Myopic R\&D Investment Behavior, ,The Acounting Review”, vol. 73.

Chung K.H., Pruitt S.W. (1994), A Simple Approximation of Tobin's q, „Financial Management", vol. 23, nr 3, https://doi.org/10.2307/3665623. 
Comporek M. (2019), Urealniony wymiar oceny zarzqdzania zyskiem w przemysłowych spółkach giełdowych, „Przedsiębiorczość i Zarządzanie”, t. 19, z. 1.

Comporek M. (2020), Zarzqdzanie wynikiem finansowym w przedsiębiorstwach. Wymiary, modele, ocena, Wydawnictwo Uniwersytetu Łódzkiego, Łódź.

Deng X., Ong S.E. (2018), Real Earnings Management, Liquidity Risk and Reits SEO Dynamics, ,Journal of Real Estate Finance and Economics”, vol. 56, nr 3, https://doi. org/10.1007/s11146-017-9649-5 .

Ewert R., Wagenhofer A. (2005), Economics Effect of Tightening Accounting Standards to Restrict Earnings Management, „The Accounting Review”, vol. 80, nr 4, https://doi. org/10.2308/accr.2005.80.4.1101.

Ferentinou A.C., Anagnostopoulou S.C. (2016), Accrual-based and Real Earnings Management before and after IFRS Adoption, ,Journal of Applied Accounting Research”, vol. 17, nr 1, https://doi.org/10.1108/jaar-01-2014-0009.

Gandhi K. (2019), Real Earnings Management: A Critical Review of Literature, „Prajnan”, vol. $47, \mathrm{nr} 3$.

Graham J.R., Harvey C.R., Rajgopal S. (2005), The Economic Implications of Corporate Financial Reporting, ,Journal of Accounting and Economics”, vol. 40, https://doi. org/10.1016/j.jacceco.2005.01.002.

Gunny K. (2005), What Are the Consequences of REM?, Working Paper, Haas School of Business, University of California.

Gunny K.A. (2010), The Relation between Earnings Management Using Real Activities Manipulation and Future Performance: Evidence from Meeting Earnings Benchmarks, „Contemporary Accounting Research”, vol. 27, nr 3, https://doi.org/10.1111/j.19113846.2010.01029.x.

Herrmann D., Inoue T., Thomas W.B. (2003), The Sale of Assets to Manage Eearnings in Japan, ,Journal of Accounting Research”, vol. 41, nr 1, https://doi.org/10.1111/1475679x.00097.

Hribar P., Jenkins N.T., Johnson W.B. (2006), Stock Repurchases as an Earnings Management Device, ,Journal of Accounting and Economics”, vol. 41, nr 1-2, https://doi. org/10.1016/j.jacceco.2005.10.002.

Huang X., Sun L. (2017), Managerial Ability and Real Earnings Management, ,Advances in Accounting", vol. 39, https://doi.org/10.1016/j.adiac.2017.08.003.

Jackson S., Wilcox W. (2000), Do Managers Grant Sales Price Reductions to Avoid Losses and Declines in Earnings and Sales?, „Quarterly Journal of Business and Economics", vol. 39, nr 4.

Pincus M., Rajgopal S. (2002), The Interaction between Accrual Management and Hedging: Evidence from Oil and Gas Firms, „The Accounting Review”, vol. 77, nr 1, https://doi.org/10.2308/accr.2002.77.1.127.

Roychowdhury S. (2006), Earnings Management through Real Activities Manipulation, „Journal of Accounting and Economics”, vol. 42, nr 3, https://doi.org/10.1016/j.jacceco.2006.01.002.

Schipper K. (1989), Commentary on Earnings Management, „Accounting Horizons”, vol. $3, \mathrm{nr} 4$.

Srivastava A. (2019), Improving the Measures of Real Earnings Management, „Review of Accounting Studies", vol. 24, nr 4, https://doi.org/10.1007/s11142-019-09505-z.

Thomas J.K., Zhang H. (2002), Inventory Changes and Future Returns, ,Review of Accounting Studies", vol. 7, https://doi.org/10.1023/a:1020221918065. 
Vladu A. (2015), Managerial Preferences between Accrual-Based versus Real Earnings Management, „Hyperion International Journal of Econophysics \& New Economy”, vol. 8, nr 2.

Wang S., D'Souza J.M. (2006), Earnings Management: The Effect of Accounting Flexibility on R\&D Investment Choices, ,Johnson School Research Paper Series”, nr 33-06.

\section{Comparative Analysis of the Application of Roychowdhury and Gunny Models in the Estimation of Real Earnings Management}

(Abstract)

Objective: The main aim of the article is to present the results of empirical research on the formation of abnormal production costs as well as discretionary $S G \& A$ expenditures in public companies included in the WIG-construction index. A secondary goal is to analyse the relationship between the scope of implemented real earnings management practices and the performance of listed companies, assessed on the basis of the ROA coefficient. Research Design \& Methods: Analytical formulas of Roychowdhury and Gunny models were used to determine the scale of real earnings management.

Findings: The empirical research shows that in the studied population there are statistically significant relationships between the achieved $R O A$ coefficient and the scale of implemented REM practices. The relationships between REM coefficients, distinguished by different regression models, are shown to be very strong.

Implications/Recommendations: The method used to estimate the level of discretionary SG\&A expenditures has a greater impact on the overall assessment of the scale of REM practices in an enterprise than do discretionary production costs.

Contribution: The research should contribute to the search for effective instruments for measuring company activities related to the intentional shaping of financial results.

Keywords: real earnings management, Roychowdhury models, Gunny models, construction enterprises. 